\title{
MARKET FAIRNESS IN ISLAMIC ECONOMICS LAW AND ETHICS: A Study on Modern and Traditional Market Regulations in Indonesia
}

\author{
Mustapa Khamal Rokan \\ Fakultas Syariah UIN Sumatera Utara \\ Jl. Willem Iskandar Pasar V, Medan Estate, Medan, 20371 \\ e-mail: mustafa_rokan@yahoo.com
}

\begin{abstract}
Abstrak: Keadilan Pasar dalam Hukum dan Etika Ekonomi Islam: Studi tentang Peraturan Pasar Modern dan Tradisional di Indonesia. Studi ini dilatarbelakangi kondisi pasar yang tidak adil berupa ketersingkiran pasar tradisional di Indonesia disebabkan persaingan yang tidak seimbang dengan pasar modern. Tulisan ini berusaha menemukan formulasi hukum yang adil untuk menjaga keberadaan pasar kecil. Untuk menemukan formulasi hukum tersebut, penulis akan membahas pengaturan pasar dalam peraturan perundang-undangan di Indonesia, menganalisa serta menemukan hal yang harus dioptimalisasikan untuk membuat pengaturan pasar yang adil dalam perspektif hukum Islam. Studi ini mengajukan paradigma bahwa pasar bukan hanya sebagai institusi bisnis tetapi juga insitusi ibadah dan sosial berdasarkan persaudaraan yang mengharuskan saling menghormati, saling bertanggungjawab. Terdapat preskriptif hukum untuk menjaga keberadaan pasar tradisional di Indonesia, yakni mengoptimalkan konsep kepemilikan pasar sebagai bentuk kepemilikan umum dan mengoptimalkan regulasi kerjasama antara pasar tradisional dan modern berdasarkan doktrin hukum ekonomi Islam.
\end{abstract}

\begin{abstract}
This study has been motivated by unfair market conditions in the form of marginalization of traditional markets in Indonesia due to unequal competition with the modern market. This article tries to find a fair legal formulation to maintain the existence of a small market (traditional). To find the legal formulation, the author attempts to discuss market regulation in Indonesian legislation, analyzed and found it to be optimized to create a fair market arrangements in the perspective of Islamic law. This study propose a paradigm that the market functions not only as an business institution but also as religious and social institutions based on brotherhood which requires mutual respect and responsibility. There are prescriptive law to maintain the existence of traditional markets in Indonesia, which optimizes the concept of ownership as a form of common ownership and optimize the regulation of cooperation between the traditional and the modern market economy based on the doctrine of Islamic law.
\end{abstract}

Keywords: Islamic business ethics, modern and traditional market, monopoly 


\section{Introduction}

Modern market ${ }^{1}$ presence has created market problem in Indonesia. The presence of modern markets which led to marginalization of traditional markets into a trade mostly small and medium-sized businesses. This can be seen in terms of growth, the ratio of expenditure, which shows the modern market turnover has increased, otherwise growth, turnover and traditional market expenditure ratio decreased. In fact, most of the traditional market losses and marginalized. This can be seen of the following:

In 2007 the number of outlets modern retail was 10.365 and in 2011 become 18.152 outlets, which it's means that increased eight thousand or four stores per day. The number traditional market in 2007 was 13,750 outlets, in 2011 became 9,950 outlets, which it's means that reduce 3,800 outlets, or 29 percent. In 2012 the number of modern market about 10,000 and the number modern market is 14,000 outlets with details of 358 convenient stores, 11569 Minimarket, 1,146 supermarkets, 141 hypermarkets and 260 grocery or wholesale. ${ }^{2}$ In Jakarta, growth of Indomaret rose significantly, with details 525 outlets (in 2006), became 1,115 outlets (March 2009), became 1186 (July, 2010) and became 2162 outlets (in 2011), ${ }^{3}$ while the traditional market rose stagnantly at 153 outlet since 2000.

The above facts indicate there is a problem in the Indonesian market. The problem is the market fairness. This paper will discuss the concept of a fair market in the perspective of Islamic law. Market fairness according to Islamic law based on the concept of ownership of the market and market legal principles and a number of anti-monopoly law docrine which will be explained. This paper uses qualitative methods with the case study approach and history, analyzing business norms contained in the muâmalah jurisprudence accompanied by historical approach market policies undertaken by the Prophet Muhammad at the heyday of Islam. While the case used is the decision of the Commission which is the authority in Indonesian market. The data collection method used is the literature that is the source of business law of Islam (al-Quran and al-Hadis), fatwas, market rules, scientific books written by experts of Islamic business law related to the topic.

\section{Nature of Market Fairness According to Islam}

Nature of fairness is talk of freedom and human equality. Everyone is born in a free

${ }^{1}$ In Indonesia, modern retail market has been in practice since the early sixties. Sarinah on Jalan Thamrin Jakarta is one of the largest department store that was built in 1964, followed by Aldiron Plaza1979, Duta Merlin, Ratu Plaza, Pasar Raya, Hayam Wuruk Plaza 1980s. In 1998, foreign retailers began to enter the retail business in Indonesia with characterized by Carrefour which offers one stop shopping concept as well as hypermarkets etc. Further followed by Goro, Giant Hypermarket and Makro, M. Udin Silalahi, "Persaingan di Industri Ritel Ditinjau dari Aspek Hukum Persaingan Usaha," in Jurnal Hukum Bisnis, Vol. I, No. 5, 2008, p. 27.

${ }^{2} \mathrm{http} / \mathrm{m}$.bisnis.com/industry/read.

${ }^{3}$ Ibid. 
position as a tribute to man. ${ }^{4}$ The position of human alignment bore the same rights and obligations in the conduct of expression. ${ }^{5}$ The consequences of human equality created two (2) things simultaneously the principles of freedom and the principle of responsibility.

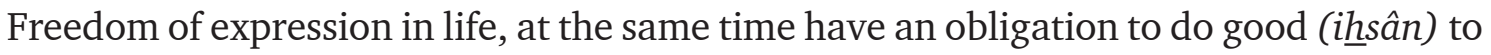
everyone. ${ }^{6}$ Therefore, fairness correlated with doing good. The form of goodness is to help and protect those who are weak, especially those who are in the vicinity of our lives. Good works do not only protection but also empowering. Allah Said: "Allah command justice, the doing of good and giving to kith and kin, and He forbids Allah decendent deeds, and evil and rebellion. He instruct you, that ye may receive admonition."”

The principle of freedom has implication to competition. Freedom to meet any need and want pose a competitive business, and even lead to economic problems. Therefore, economic freedom should be limited by the principles of sharia that required fairness. In the Islamic law for business, freedom of economic activity is limited into three requirement (1) The freedom that does not violate Islamic law.(2) The freedom that does not cause harm to his/ herself, (3) the freedom that does not cause harm to others. ${ }^{8}$

Islam teaches the principles of fairness, ${ }^{9}$ by way of compromise between freedom and responsibility. Compromise can be done by providing the opportunity for everyone to get something, but at the same time everyone should respect the rights of others to obtain something else (iḩsân). Islam justify selfishness without damaging the community order. ${ }^{10}$ Therefore, every individual has the right to make freedom but also have a social responsibility to the people who were around him, especially against people or people who are weak and closest to any person whomsoever, ${ }^{11}$ thus forming a peacfull social co-existence.

Based on the principle of equality, the Prophet Muhammad build fair economic system in the city of Mecca. Trading condition in Mecca is monopolistic, ${ }^{12}$ and reformed by the

4'Âli ibn Abî Thalib said ...do not be al slave of others because Allah has created you free. See, Behechti \& Bahonar, Philosophy of Islam (Iran: Ansyariyan Publication, 1990), p. 414-415.

${ }^{5}$ Therefore, fairness can be divided to economic fairness in the distribution of income and economic fairness in equality which requires every individual should have the opportunity to access the economy. Mawardi, "al-'adalah Concept in Islamic Economic Perspectives," in Journal of Islamic Law: Vol.VII, No. 5, July 2007, p. 53.

${ }^{6}$ Q.S. al-Nahll/16: 90.

${ }^{7}$ QS. al-Nahl/16: 90.

${ }^{8}$ Abdul Azhim Islahi, Economic Concept of Ibn Taymiyah (Leicester UK: The Islamic Foundation, 1998), p. 225.

${ }^{9}$ Fazlurrahman, Islam and Modernity: Transformation of Intellectual Tradition (Chicago: The University of Chicago Press,1982), p. 2.

${ }^{10}$ See Afzalur Rahman, Doktrin Ekonomi Islam (Yogyakarta: Dana Bhakti Wakaf 1995), p. 10.

${ }^{11}$ Q.S. al-Baqarah/2: 177.

${ }^{12}$ According to Nurcholish Madjid, short letters that become verses in Makkiyah is criticism of monopolistic conditions and emphasizes the doctrine of monotheism and social fairness.See, Nurcholish Madjid, Islam, Kemodrenan dan Keindonesiaan (Bandung: Mizan 1987), p. 158. Esposito 
Prophet with the principles of market fairness. It can be seen from the criticism of the Quran against exploitative trading activity, monopolistic, such as the prohibition of usury, ${ }^{13}$ taken advantage without an agreement, ${ }^{14}$ reducing the weight scale ${ }^{15}$ and so on. The Qur'an also criticized the behavior of abandoning people who are weak and hedonistic and materialistic attitudes resulting in social inequalities. ${ }^{16}$ The mission of Quran is to remove the socio-economic gap that is going on in the city of Mecca. ${ }^{17}$

The essence of human freedom and equality comes from God (divine). Monotheism is the belief in the teachings of the unity of creation, human unity, the unity of life guidance and unity of purpose in life so that every human being has the same position and status (egalitarian) before God and history. ${ }^{18}$ Therefore, economic activity should be based on the values of Tawheed which contains the goodness that is universal as the values of honesty, brotherhood, silaturrahim, social, cooperation and mutual responsibility among business people(takâful al-ijtimâ’iyyah).

Based on this, the market as a place of business transactions not only on the economic dimension as such, but part of the socio-cultural and living law based on divinity.Thus, the market is not only the legal norms relating to the economics of legal norms, but the sociocultural dimension of legal norms that are integrated in the values of divinity.

Therefore, economic fairness can not be separated from social fairness. According to Sayyid Qutb social fairness based on the principles of providing adequate opportunity, and the principles of fairness among them. ${ }^{19}$ Fairness does not mean giving/treating the same to everyone. Fairness is giving/ attitude in accordance with the place, and any given situation. Attitude of leveling between the strong and the weak (bi taswiyatuhâ bi al-isti'dâdâti aldha'îfah wa naghluhâ 'anil 'amal) is a form of tyranny. According to Qutb, the differences among humans (strong and weak) is constituting way to create social fairness by taking into account all the values and elements broadly. ${ }^{20}$

Different attention to those who has capacities and the weak ones aiming for a balance

describe the current condition of injustice Mecca, However, the situation in commercial towns such as Makkah was different. Here markets operated freely and great differences in wealth left the poor, orphans and women at the receiving end of exploitation and injustice. See, John L. Esposito, "The Islamic Threat: Myth or Reality?," in Zafar Iqbal and Mervyn K. Lewis (ed.), An Islamic Perspective on Government (UK: Edward Elgar Publishing Inc., 2009), p. 68.

${ }^{13}$ See, Q.S. al-Baqarah/2: 278-279; Q.S. al-Rûm/30: 39; Q.S. al-Nisâ/4: 160-161; Q.S. Âli 'Imrân/3: 130.

${ }^{14}$ Q.S. al-Nisâ'/4: 11.

${ }^{15}$ Q.S. al-Muthaffifîn/83: 1.

${ }^{16}$ As not sympathize orphans, abandoned the poor. Q.S. al-Mâ‘ûn/107: 1-3.

${ }^{17}$ W. Montgomery Watt, Pergolakan Pemikiran Politik Islam, transl. Hamid Fahmi Zarkasyi (Jakarta: Beunebi Cipta, 1987), p. 4.

${ }^{18}$ Amiur Nuruddin, Keadilan dalam al-Qur;an (Jakarta: Hijri Pustaka Utama, 2008), p. 19.

${ }^{19}$ Sayyid Quthb, al-Adâlah al-Ijtimấiyyah fi al-Islâm (Egypt: Dâr al-Syuruq, 1979), p. 36.

${ }^{20}$ Ibid. 
in society. ${ }^{21}$ In many verses, the Qur'an requires giving attention to those poor and weak in order to create a balance of society. Community imbalance is in contrary to the spirit and commitment as well as the principles of brotherhood and social fairness. The gap should be reduced even removed by providing economic access and protection to everyone actively in the process of good economic production, distribution, circulation and consumption. The balance of society can be realized by mutual guaranteeing basic needs fulfillment, and mutual guaranteeing social needs (Social economics security insurance, takâful al-ijtimâ). ${ }^{22}$

\section{Market Fairness Doctrine}

Market fairness doctrine can be built with three doctrines i.e. market as public ownership, the doctrine of trade and ban deterrence doctrine (restraint of trade) in trade will be explained as follows:

\section{Market Ownership in Islamic Law}

Market as a place for transactions are included in the category of public ownership (al-milkiyyah al-âmmah). Common ownership market philosophy is that everyone can have the same opportunityto access the market as a source of economy. In simple terms that anyone who comes first then is entitled to obtain a trade on the spot. Ali bin Abi Thalib said that market for Muslims as our prayer place, whoever come first has the rght to occupy it unless otherwise rejected. ${ }^{23}$ In contrast to the concept of state ownership (al-milkal-Daulah) where countries are still allowed to give rights to individuals or private ownership, while the concept of common ownership (al-milkiyah al-âmmah) that the state should not provide management rights to anyone ${ }^{24}$ except for a shared and common interests.It is based on

${ }^{21}$ Q.S. al-Dzâriât/51: 19; Q.S. al-Nisâ/4: 75; Q.S. al-Baqarah/4: 177.

${ }^{22}$ M. Syafii Antonio, Bank Syariah: Wacana Ulama dan Cendekiawan (Jakarta: Tazkia Institute, 1999), p. 50.

23'Alauddîn 'Alî Muttaqî Husâmuddîn al-Hindî, Kanz Al-'Ummâl fi Sunan al-Aqwâl wa alAf'âl, Juz. V (Beirût: Muaasasah al-Risâlah, 1985), p. 816.

${ }^{24}$ Restrictions on property rights is intended to realize the egalitarian distribution of wealth in accordance with the spirit of Islam. M. Umar Chapra, Islam and Economics Development (New Delhi: Adam Publishers \& Distributors, 2007), p. 73-74. See also Ridwan, Kepemilikan Tanah terhadap Masyarakat dan Negara Menurut Hukum Islam (Jakarta: Training and Development Agency and the Ministry of Religious Affairs, 2010), p. 98 in the footnote number 57. 
the principle of market fairness exemplified by the Prophet Muhammad and friends ${ }^{25}$ the time to manage the market of Medina which is universally applicable principles of all time. ${ }^{26}$

Legal norms on the ownership in market as common ownership (al-milkiyyah al'âmmah) aims to prevent (sadd zarîh) any activity that may create the monopolistic practices by some people. If someone does (monopolies) or a group of people (oligopoly) with controls or has the market can lead to trouble and distress for the general public. ${ }^{27}$ Monopoly practices can occur by giving ownership of the free market (liberal) to businesses that have large capital capabilities that can make small businesses being eliminated so that the market is unfair.

Concept common ownership market as the market requires the rule of law has no restrictions on the ownership of public ownership through the market as state power. Therefore, the market definition should impose limits on the authority of the development, management and ownership of government-run market as interest lives of many people.

\section{Principles of Cooperation}

The principle of cooperation is a prerequisite for economic fairness. Al-Quran states that in order tha it may not (merely), make a circuit between the wealthy among you....". ${ }^{28}$ The principle of cooperation will create market conditions of mutual respect, keep between, ${ }^{29}$ one party and another party in order to obtain mashlahah together. Thus, every business should not pursue individual interests and benefits without seeing the condition of the brothers in the vicinity. A businessman is not dissatisfied with personal success while others being marginalized in businesses.

Moreover, the principle of cooperation aims to create a healthy economic system and orderly society (social order). Unhealthy economic system is the premise for the emergence

\footnotetext{
${ }^{25}$ The second legal basis is the practice of the policy pursued by 'Umar when he saw a kiosk that was built by someone in the market of Medina and he knocked him out.In another narration the Prophet forbade the establishment of the building, this policy was continued by 'Umar ibn al-Khattab that form the basis of ownership market including stores that are in it are whollyowned state that can not be delegated to those individuals or private legal entities. Abî Shaybah, Abu Bakr 'Abd Allâh bin Muhammad (1409/1989). Juz. IV, Al-Kitab al-Musannif Al-Ahadis wa AlAtahar, 488, Ibn Shabbah, Abu Zayd 'Umar b. Shabbah (1399/1979), Juz.II, Tarikh al-Madinah al-Munawwarah, (ed. H. Mahmud Ahmad). Jeddah, 750. Allamah Alauddîn 'Alî Muttaqî Husâmuddîn al-Hindî, Kanz Al-'Ummal fi Sunan al-Aqwal wa al-Af'al, p. 815. See Note also, M. J. Kister, The Market of Prophet, Journal of the Economic and Social History of the Orient, Vol. 8, No. 3, Dec., 1965), p. 237.

${ }^{26}$ Arief Hoetoro, Ekonomi Islam: Pengantar Analisis Kesejarahan dan Metodologi, (Surabaya: Bayumedia \& BPFE Unibraw, 103 (2007), p. 103. in footnote number 8.

${ }^{27}$ Abdul Azim Islahi, Konsep Ekonomi Ibnu Taymiyah, Translated by Anshari Thayib, Surabaya: PT. Bina Ilmu, 1997), p. 144.

${ }^{28}$ Q.S. al- - $a s y r / 59: 7$.

${ }^{29} \mathrm{Abdul}$ Halim Hasan, et al, Tafsir Al-Quran Karim, Six Edition, (Medan: Firma Islamiyah, 1957), p. 77
} 
of chaos, destruction and murder in the community. ${ }^{30}$ Cooperation is the principle of creating unity of society so as to establish a harmonious society. Abûl A’la Maudûdî said:

Important objective of economic system of Islam is promotion and sustainability of society's unity and cohesion. Islam is the torchbearer of human unity and brotherhood, and is opposed to division and disharmony. ${ }^{31}$

The principle of cooperation in Islamic economic law is implemented in the form of contract-agreement. Philosophy covenants contained in the law of Islamic economics is to cooperate. Such contract is a contract mudhârabah cooperation agreement between the owners of capital ( $r a b$ al-mal) with the fund users (mudharib) used for productive activities where profits are divided into two or by both agreement. ${ }^{32}$ Musyârakah agreement is cooperation between the owners of capital and skills, musâqah is an agreement in the field of plantation, muzhâra'ah is an agreement in the field of agriculture, contract ijârah (lease) and so on.

Islamic economic laws have patterns of cooperation such as shirkah 'Inan, shirkah' Abdan, shirkah a-Wujuh, shirkah mufâwadhah, and shirkah a-profit. ${ }^{33}$ During its development, forms of cooperation pattern can be modified according to the current business developments, such as the provision of space cooperation, sales of products for small businesses, the coreplasma system, as long as not contrary to sharia and the principle of sharing.

The principle of cooperation aimed at minimizing the income inequality among businesses. By cooperation, businesses profit gain together though with different portions, according to the abilities/skills of each economic actor. Conversely, without cooperation, profit and wealth is concentrated in one or a certain group of people. The opposite of cooperation is monopolies. Monopolistic practices and unfair makes business competition distributions concentrate only on one person or a group of businessmen. Strong business operators will dominate the market, while small businesses were eliminated. Allah Said: Oh ye who believe, eat nor up yor property amoung yourselves in vanities, but let there be amongst you traffic and trade by mutual good will: nor kill yourselves. ${ }^{34}$

Business activities are categorized as tort (vanity) in the above paragraph is a business activity that is carried out by means of mutual cooperation not liking each other(al-ridha). One form of business activity that is not based on mutual respect is monopolistic practices

${ }^{30}$ Kamal Faqih Imani, Tafsir Nurul Quran (Jakarta: Al-Huda, 2004), p. 4.

${ }^{31}$ Sayyid Abu al-A'la Maududi, First Principle of Islamic Economics, transl. Ahmad Imâm Shafaq Hashemi (UK: Islamic Foundation, 2011), p. 90.

${ }^{32} \mathrm{M}$. Fahin Khan, Essay in Islamic Econmics (United Kingdom: the Islamic Foundation, 1995), p. 80.

${ }^{33}$ Islahi, Konsep Ekonomi Ibnu Taymiyah, p. 194.

${ }^{34}$ Q.S. al-Nisâ'/4: 11. 
such as strong businesses monopolizing weak businesses. ${ }^{35}$ This understanding is obtained in the next paragraph the phrase "do not kill yourself" are not defined in terms of killing the soul and blood, but also in trade. In a competitive business, business people can "kill" other businesses in order to earn huge profits. ${ }^{36}$ Based on the above paragraph, the requirements of fairness is a system of cooperation among businesses people. Cooperation in question is a partnership between strong businesses and weak businesses so that weak businesses are not eliminated who will not be able to compete with large businesses.

\section{Principle of Prohibition on Trade Barrier}

\section{Talaq Rukban Doctrine (Restraint Doctrine)}

Market fairness based on prohibition on trade barrier (talaq rukban). This Doctrine is the oldest doctrine in antitrust law that was born in the 5th century, when the Prophet Muhammad set the market of Medina. In the tradition of the common law doctrine of freedom of the barriers to entry of new market emerged in the 16th century as the doctrine of restraint of trade which is absorbed by the US Sherman Act. ${ }^{37}$ This doctrine is derived from the traditions of Muhammad that prohibits intercept traders who have made it to market.

Doing barriers against other businesses into the market led to the market is not going to work according to the mechanism. Behavioral inhibition in the trade implications on market volatility as the price and so on. Prophet Muhammad wanted to make sure that the market price becomes stable and the price can not be manipulated by the intermediary and the price maker. ${ }^{38}$

\section{Doctrine on lhtikâr Prohibition}

Market fairnessbased on the doctrine of ihtikâr prohibition

${ }^{35}$ M.Quraish Shihab defines "vanity" in general that as a violation of the terms or conditions agreed religion. M. Quraish Shihab, Tafsir al-Misbah (Jakarta: Lentera Hati, 2002), p. 412.

${ }^{36}$ Muhammad 'Abduh, Tafsir al-Manar, Vol. V, as quoted by Sheikh Abdul Halim Hassan, et al., Tafsir al-Quran Karim, p. 77 with some editorial changes without losing the substance.

${ }^{37}$ This case arose from the granting of a monopoly by the Queen of England to Edward Darcy with a company named Ralph Bowes \& Co. to create or import of playing cards (playing cards). In the market has kind of playing cards traded by T. Allein, therefore, Darcy felt disturbed and may file a suit. More see Stephen F. Ross, Prinsiples of Antitrust Law (Wetbury, New York: The Foundation Press, Inc., 1993), p. 12-13.

${ }^{38} \mathrm{It}$ is known that the majority of traders in Medina is an importer that sells merchandise on arrival in Medina good for newcomers or to intermediaries (agents). (ba'y present li Bâdin). Mohammad Hashim Kamali, "Tas'ir (Price Control) in Islamic Law." The paper was prepared for Colloquim Entitled "The Bazaar in the culture and civilization of the world of Islam, which was to been held in Tabriz, Iran, p. 31

${ }^{39}$ The doctrine of ihtikar prohibition contained in the Quran and the hadith of the Prophet. 
meansdamage the social ties (isa ul mu'asyarah), or holding goods for high price. ${ }^{40}$ By the term, means habsu al-sal'i an bay, ${ }^{41}$ (hoarding or detention of goods from circulation), or ba i'ussal'i yuakhir al-sal'i yanzhuru bihi ghala 'al-as'ar (storage of goods by the seller to wait soaring food prices and the current selling price has soared). In a hadith mentioned "Anyone who do monopoly is sinner." 42

Practice ihtikâr damaging relationships between businesses with other businesses shut down by holding certain goods and services. Ihtikâr goal is to withstand circulation (supply) that is smaller than the demand (demand) and take advantage of the the to situations. Traders detaining the goods will gain great advantage of these conditions. Umar bin Khattab has ever sentenced those who hold goods, because such actions can make other people die with unfair competition as the current economic crisis and inflation. ${ }^{43}$ I $\underline{h}$ tikâr can make the market run is not perfect, because the price of goods can be up high. Hoarding is a very easy way to make a profit, because scarcity will cause the price of goods to rise and that's when the owner of the goods to sell goods in the market.

\section{Doctrine on Ta'alluq Prohibition}

Ta'alluq term means conditional sale and purchase. A business operators will sell anything to other businesses, if other businesses do the terms specified. The reasons which led to the sale and purchase ta'alluq is prohibited due to gharâr element gharâr elements contained in uncertainty for businesses and consumers to the continuation of a contract between the parties, due to the conditions. According to Mazhab Hanafi make ta'liq (the hanging) in the transaction are included in the category qimâr (gambling). ${ }^{44}$

Ta'alluq doctrine has been adopted in the book of the law of civil law of the Turkish government Ottoman book Majallah al-Ahkam al-Adliyah. Article 189 said: "A sale with a condition, which is not for the benefit of one of contracting parties, is lawful, but the condition is bad." 45

See Q.S. al-Mâ'idah/5: 2; Q.S. al-Baqarah/2: 279, Q.S. al-hajj/22: 78, Q.S. al-Mâ'idah/5: 6. Some of the traditions of the Prophet Muhammad. which prohibits and condemns behavior ihtikar:

${ }^{40}$ See, Imam Muslim, Sahih Muslim (Beirut: Dâr al-Fikr, 1986), p. 312.

${ }^{41}$ Muhammad 'Ali al-Syaukani, Nail al-Author (Egypt: Mustafa al-Babi al-Halabi, n.d), p. 235.

${ }^{42}$ Imam Muslim, SahihMuslim, p. 312.

${ }^{43}$ Zulkifli Hasan, "Islamic Perspectives on the Competition Law and Policy," in files.wordpress. com/2008/.../Islam-and-competition-policy.

${ }^{44}$ Al-Dâr al-Mukhtâr, Ibn Abî Dîn in Husain Syahatah, and Siddiq Muh. Amin Adh-Dhahîr, alGharar fi al-'Uqud wa Atsaruhu fi al-Thabiqat a-Mu'ashirah, transl. Saptono Budi Satryo and Fauziah, Transaksi dan Etika Bisnis Islam (Jakarta: Visi Insani Publishing, 2005), p. 160.

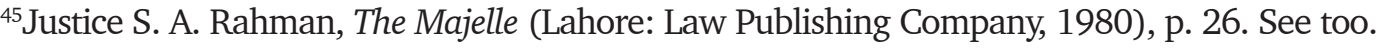
H.A. Jazuli, Kitab Undang-undang Hukum Perdata Islam (Bandung: Kiblat Press, 2002), p. 33. 


\section{Fair Market Regulation in the Perspective of Islamic Law: the Case of Indonesia Ownership Regulation in Indonesian Market}

Market regulation in Indonesia gives ownership and management of the market not only to the government but also to parties other than the government. It can be seen from the definition of the modern market that does not define the market on an aspect ownership, management and development. Likewise, the definition of traditional markets provide the right development and market management to the government, private, StateOwned Enterprises (SOEs) and the Regional Enterprise (ROE), or cooperation with the private sector. ${ }^{46}$ Regional Market Regulation governing the management of traditional markets to the authority of the market managers Provincial Market, Market District/ City, Village Market, Private Markets are managed directly by the local government (provincial, district/city, village) and Private. Private markets are defined as markets created, organized and managed by the private land or land held by the private sector. ${ }^{47}$ It can be concluded that the development and management of Indonesia's market can be divided into five (5) agencies, the government, private, state enterprise, local enterprises and private cooperative. Thus, regulating the market ownership in Indonesia can be owned by anyone independently.

\section{Market Fairness in Indonesia Based on the Market Ownership}

Fairness in the Indonesian market can be realized with the concept of the market as a public property ownership (al-milkiyah al-'âmmah) so that the market can not be freely used by all parties. Regulating market in Indonesia, which allow the market created, organized and managed by the private land or land held by private is not in line with Islamic law. The concept of common ownership to the market because the market is of interest to everyone, because the absence in the public market could lead to disputes in society. Liberally granting permission to the private sector, including foreign retail companies could cause the market share held by only certain businesses as entrepreneurs who have capital and a strong network.

Market regulation should cover aspects of ownership, capital and management rights to ensure the authority of state on the market as common ownership. The formulation of the modern market by looking at aspects of ownership, capital and management is essential to ensure ownership of businesses on the market. ${ }^{48}$ The distinction formulation capital

\footnotetext{
${ }^{46}$ See Article Article 1 paragraph 2 The Trade Ministery Regulation No.53 Year 2008.

${ }^{47}$ Article 1 paragraph 8 of Batam City Regulation No.10 of 2009 on the Management and Development Market in Batam.

${ }^{48}$ In some Regional Market Regulation has classified the modern shop with a modern shop with one hundred percent of domestic capital to create different rules.Modern shop with one hundred percent of domestic capital has sales floor area of less than $400 \mathrm{~m} 2$ for Minimarket, sales floor area of less than 1,200 m2 for Supermarket, sales floor area of less than 20002 for Department Store. See Article 21 paragraph (2) Regulation Megelang District Market.
} 
ownership including foreign capital needed to maintain the sovereignty of the state on economic resources of society in the retail market.

The debate occurred in two (2) things namely, first in terms of ownership with management rights, second, the right of every person to be able to gain access to the market as to its nature as a common ownership (al-milkiyyah al-âmmah) while the market is limited (limited sources) that not everyone is able to be accommodated to gain access to or benefit from the market.

In terms of terminology ownership right and management rights. In principle of ownership right and management rights is a unity that can not be separated. Market philosophy as an institution of common ownership (al-milkiyah al-âmmah) aims to ensure that everyone can benefit from the market. In addition, the market also can not be monopolized by certain people who have a strong capital. Therefore, the right of ownership and management rights should be in the country. Therefore, countries are is a legitimate institution managing common ownership and given profusely to the people. The state does not have the right to act beyond its authority as the manager of such grant management rights to private parties. ${ }^{49}$ The common property rights that have been managed by the state through the state or a business entity may be the property of the state through nationalization as Stateowned enterprises (SOEs)/Regional Owned Enterprises (enterprises) where the benefits should be used as much as possible for the prosperity of the people thoroughly. ${ }^{50}$

Strengthening of market regulation contained in the ownership arrangements by licensing system. Freely licensing conflict with the state's duty to protect the public from monopolistic practices. It is based on legal norms "La dharara wa la Dhirar" ${ }^{11}$ (no loss or disadvantage).This method is prohibit property owners take advantage of the properties benefit that cause direct harm to others. The phrase "dharar" according Baqir Sadr means exacerbating someone both directly, and indirectly. ${ }^{52}$

In the case where the market is limited (limited sources), where not everyone is able to be accommodated to gain access to or benefit from the market, then the state can make certain criteria based on the principles of equity and in accordance with the interests of the market such as the moral aspect, motivation etc.

\footnotetext{
${ }^{49}$ Yusanto and Yunus, Pengantar Ekonomi Islam, p. 151.

${ }^{50}$ Fathurrahman Djamil, Hukum Ekonomi Islam: Sejarah, Teori dan Konsep (Jakarta: Sinar Grafika, 2013), p. 206-207.

${ }^{51}$ Muhammad Musthafa al-Zuhaili, Al-Qa'idah al-Fiqhiyyah wa Tathbiqiha fi Al-Madzâhib al-Arba'ah, Juz I (Dimsyiq: Dâr al-Fikr, 2006), p. 199.

${ }^{52}$ Muhammad Baqir al-Sadr Ash, Parent Book of Islamic Economics, (Iqtishaduna) (Jakarta: Zahra, 2008), p. 580. In case of fire Monday Market, Jakarta, for example, traders really hope the government does not submit pascakebakaran management to the private sector for fear prices stall traders increasingly expensive and troublesome. See, "Private Do not Go," in Kompas, Monday, April 28, 2014, p. 1.
} 


\section{Endowments Legal Entity: Alternative Market Ownership}

One of the Islamic economic instruments associated with common ownership is wakaf (endowment). Endowments are Islamic economic instruments at once continuous elastic nature. Called elastic, because the waqaf property does not have to be tied exclusively intended for certain groups such as charity but can be used for the benefit of mankind in general and can cover all aspects. Continuous called because one of the properties of waqf property must not be discharged (baqâ'), so that the nature of waqf property in philosophy requires continuous productive waqf property (sustain).

One of the success of the waqf in economic development, especially the market in the history of Islam is in Yazd, Iran. Michael E. Bonine in his article titled Islam and Commerce: Waqf and the Bazaar of Yazd, Iran (Islamic und Handel: Waqf und der Bazar von Yazd, Iran) describes in detail the close relationship between endowments and market in Yazd, Iran which is influenced by the concept of endowments property ownership. ${ }^{53}$ In Yazd, Iran, charitable institutions not only to build the infrastructure that is religion such as mosques, madrasas, tombs and so on but endowments also build infrastructure to meet the needs of many people, especially the infrastructure of commerce, namely market.Treasures in the form of endowments may take the form of ownership of the shops, and also connected with what is called the Bazaar in which there is the concept of trade and religion in an integrated manner.

In the context of the protection of traditional markets in Indonesia, endowments instrument can be an alternative to protect and empower traditional markets in Indonesia. ${ }^{54}$ The nature of waqf property that still makes all businesses can access the markets. Thus, small businesses and large there is no difference in market access that market becomes a place that is open to everyone.

\section{Aspects of Cooperation}

\section{Regulating the Cooperation System}

Legislation in Indonesia has regulated trade cooperation. Government Regulation No. 44 of 1997 concerning the Partnership noted that the partnership is a business cooperation

${ }^{53}$ In a broader scope, endowments not only affects the attitude and the religious domain but also directly affect the layout of the city (city structure) where there are markets, government offices, mosques, schools and so forth Michael E.Bonine, Islam and Commerce: Waqf and the Bazaar of Yazd, Iran (Islamic und Handel: Waqfund der Bazar von Yazd, Iran), Erdkunde, Bd. 41, H. 3 (September, 1987), p. 185.

${ }^{54}$ The practice of such "market endowments" has actually been going on since a long time in Indonesia as well as the practice of "market shock, "bazaar" in a certain momentum and so on. However, if the market shock or bazar only temporary, while the market derived from waqf property market activity can be permanently so that management can be done in a planned and professionally. 
between small businesses with medium and large businesses including mentoring and development initiated by medium and large enterprises with the principle of mutual need, mutually reinforcing and mutually beneficial. ${ }^{55}$ Trade Partnership also regulated in Presidential Decree No.112 of 2007 and the Regulation No. 53 of 2008 and the Regional Market Regulation, which requires a modern market implement partnerships with small businesses. As for some form of cooperation is in terms of marketing (marketing), providing a place of business (space), product acceptance, the sales price or rental fees in accordance with the capability of Micro, Small and Medium Enterprises. ${ }^{56}$

In principle that Indonesia legislation has reflected the principle of cooperation in Islamic law. However, this necessitates the strengthening regulation in two things:

\section{Cooperation in a Balanced Position}

Perspective of Islamic law requires cooperation on an equal footing. ${ }^{57} \mathrm{Al}$-Qur'an forbids gain from the transaction unequally (al-ridhâ). ${ }^{58}$ In history, relations major market players and small market, trading system before the Islamic done unfairly between large market with a small market. ${ }^{59}$ Large market in the period before Islam dominated by foreign traders who trade expanding to various places in the Arabian peninsula. Trade relations between traders outside (nomadic) with local merchants do not have a mutual relationship that is based on a balanced mutual help and economic exchange.

In a partnership arrangement between traditional and modern market in Indonesia puts traditional markets become part of the modern market, not equal partners. Although market regulation states based on the principles of equality and fairness between the two markets, but the majority of the patterns of cooperation puts the traditional market system dependent (subordinate) to the modern market.

It can be seen from inequality cooperation in provision of land/space. Most of the

${ }^{55}$ Article Chapter I General Provisions Article 1 paragraph 38 of Government Regulation No.44 of 1997. See also Article 1 paragraph 15 Market Regulation Yogyakarta. Presidential Decree No. 112 In 2007, the Regulation No. 53 of 2008 and Regulation of Regional Markets make PP 44 of 1997 as a preamble in the regulation of the partnership.

${ }^{56}$ Article 8 of Regulation Market Denpasar. See also Article 41 letter Kendal Market Regulation

${ }^{57}$ See, Robert Simon, Meccan Trade and Islam (Problem of Origin and Structure), transl. Feodora Sos (Hungaria: Akademiai Kiado, Budapest, 1989), p. 79-90.

${ }^{58}$ Q.S. al-Nisâ'/4: 29.

${ }^{59}$ According to al-Afghani Saaid there are three types of market on the eve of the Islamic presence. First, markets are under foreign rule (Reviews those under foreign supremacy) which is like Hira Market, Busra and others. Second, the market is made by the Arabs themselves with their own wares like Ukaz Market. Third, the market due to its geographical location used as a meeting place for foreign merchants (outside) as Suhar Markets and Market Aden where there is a character that appears while the business of local character (national) backward or decreases (at-tabi alMuttahida) Robert Simon, Meccan Trade and Islam (Problem of Origin and Structure), p. 79-90 
Local Regional Market Regulation does not require modern markets provide land for the traditional market. While some regional market regulation has required that modern markets provide land/space for traditional markets but have not set up an equivalent system and mechanism in cooperation provision of land, for example, the system profit, cooperative mechanism mediated by the local government. In addition to not knowing the opportunities for cooperation with large businesses, small businesses are also difficult to get the opportunity to cooperate. Position of small business as request to to provider (large business), not as an equal partner.

Equal in the relationship between traditional and modern market and the relationship between suppliers and modern shops can use profit sharing system. Profit Sharing System in relationship between the supplier and modern shops can use profit sharing scheme (Musharaka) or mudaraba or other forms. Distribution of the results based on a percentage of sales or profits in the provision of land will be created between the modern market and between suppliers and supplied equal and fair position.

\section{Forming a Partnership}

Cooperation modern market with traditional markets should be done with a certain pattern. Cooperation system done without model will run in effectively. Market research results in Purbalingga about partnership implementation mandated by Presidential Decree No. 112 of 2007 and the Permendag Regulation No. 53 of 2008 shall not be able to run properly due to a partnership that does not exist. ${ }^{60}$ The results of the research shows small businesses are not aware of opportunities and model of cooperation that can be done with a larger player.

Partnership model of modern shops and traditional markets can be adapted to the needs of the area where the market stands. For areas that have many manufacturers for example, a partnership should be more emphasis on joint marketing of production results in the local area.Whereas in densely populated areas, in addition to joint marketing, cooperation can be shaped pattern of land administration/ space, reprocessing (repackaging) and other patterns that can be customized with ba'y salâm, istishnâa, ijara, and so forth.

\section{Cooperation Regulation on Type and Price of Product}

Cooperation of traditional and modern market should be done by arranging the type of product. Historically, one of the Medina market regulatory policy at the time of the Prophet Muhammadis setting the type of product. Although the nature of the arrangement are still simple, but setting the classification of goods/products for a wide range of goods

\footnotetext{
${ }^{60}$ Wede Kupita and Rahadi Wasi Bintoro, Zoning Policy Implementation Traditional Market and Modern Market (Studies in Purbalingga), Supra Note. p. 51.
} 
has been made of the Prophet Muhammad. Prophet Muhammad arranged shopping area specific policies for certain goods. Samhudi said: The Prophet also made other arrangements to ensure an orderly market system. For example, he set up "departments" in the market by designating different sections for various goods. Sources report several traditions that mention special shopping areas for slaves, livestock, textiles, food-stuffs, perfumery, etc. ${ }^{61}$

Setting the type of product is also performed during the Abbasid Caliph in Andalusia market. In Andalusia Market differentiation is not only related to the type of goods, but also the price of the goods. Prices of goods are expensive separated by low freight rates which means the price of high-quality goods at prices differentiated quality goods lace $h$, local products and outdoor products and so on. More Mohammed Abdah Hatamlah in his essay: "The Andalusian Economic Era": The goods sold in Andalusian markets were subject to determined specifications, which had to be strictly observed. The perfume tradesman, forinstance, was not allowed to adulterate high quality fragrances with low quality ones, or local brands with imported ones. ${ }^{62}$

The purpose of product differentiation regulatory cooperation is to close (sadd) some businesses being excluded from the competition with a larger player. With differences in the type and price of the product, it will automatically distinguish types of consumers making large and small markets waking existence. Moreover, regulating market by type of product is also an opportunity to empower certain products in the market.

Therefore, the strengthening of setting different types of products on the retail market in Indonesia can be done in at least three (3) forms:

First, strengthening the type of product differentiation between modern and traditional markets. Distribution of different types of products at all difficult to do, because it can cause difficulties for consumers to obtain the desired product. One of the advantages of the modern market is the completeness of all kinds of goods on hand so that consumers can buy all their needs and desires completely. Therefore, to apply fair market the distinction of products need to be strengthened.

To specify the type of product it is necessary distinction survey on the establishment of the modern market area, because the difference between the market of products of modern and traditional markets associated with the condition, the potential and the type of typical regional products so typical regional products and types of products sold by the shops/stalls around the market Modern can be maintained its existence.

\footnotetext{
${ }^{61}$ Nûr al-Dîn Abû Hasan al-Samhûdi, “Wafa' al-Wafa' bi Akhbar Dâr al-Mustafa," in Muhammad Nejatullah Siddiqi (ed.), Encyclopaedia Islamic Economics, Principles, Definition and Methodology, Vol. I (London: FIF, 2009), p. 122.

${ }^{62}$ Muhammed Abdah Hatamlah, "The Andalusia Economic Era," in Muhammad Nejatullah Siddiqi (ed.), Encyclopaedia Islamic Economics, Principles, Definition and Methodology, Vol. I (London: FIF, 2009), p. 269.
} 
Ministry of Trade Decree No. 70 /2013 prohibits Minimarket to sell fresh product in bulk form is a form of progress in product differentiation with shops/stalls that are nearby location. However, further analysis is required the types of products that made the difference (distinction) between store Minimarket with traditional markets, especially in shops/stalls that are nearby distance, because in practice that there is no difference in the type of products sold in modern stores like Minimarket with stalls/shops in the surrounding areas.

In general, the type of product differentiation can be done by dividing the type of product on the traditional market selling basic food ingredients, while the modern type of product on the market is the needs of people who are secondary needs. The existence of traditional markets will remain intact because the staple food ingredients a product which can not be ignored by society such as rice, vegetables, sugar, salt and so on. In addition, basic food needs do not require traditional processed so that market participants do not have to compete with businesses in the modern market.

Second, the establishment of special markets. Some regional market regulation has made rules about the type of market division into a market selling a particular product called Special Markets such as Animal Market, Ceramics Market, Bird Market, and the like. Establishment of Special Markets associated with purchasing power and the level of consumer demand for a particular product.Government through market policies can establish niches. In some European countries, such as in the UK there are some specialized markets such as retail markets shoes and bags and other items that are not united with other product that can create competition and protection system will be easier.

Third, the different market based on price of goods. Besides product differentiation, to protect traditional markets can be done with distinction price and quality of goods in the respective markets. Thus, consumers will be able to differentiate themselves shopping options.

\section{Case of Cooperation: Analysis of Decision No.02/KPPU-L/2005 According to the Islamic Law}

Application of the principle of fairness in the market ta'alluq doctrine can be applied to the case of PT. Carrefour in the Commission's Decision No. 02/KPPU-L/2005. Commission Decision No. 02 / KPPU-L/2005 regarding the application of trading terms conducted by PT. Carrefour Indonesia ${ }^{63}$ (hereinafter referred to as PT.CI) to its suppliers. Trade relations between PT. CI with suppliers is through trade agreements for supplies, along with the

${ }^{63}$ PT.CI is a retail company that has business activities include general trading such as convenience stores, supermarkets, hypermarkets and the establishment of the building to be used as a place of business. PT RATAH TIMBER CI was established as PT Contimas Utama Indonesia (CUI) in 1995. On December 23, 2003, PT Cartisa Property Indonesia, PT Carti Satria Supermarkets and CUI merge into one company under the name of PT. CI.See, the Commission's Decision 02/KPPU-L/2005. 
terms of trade (trading terms) as listing feeminus margins and so on. ${ }^{64}$ Suppliers (suppliers) must follow a number of favorable conditions PT.CI in the competition in the retail market, and if the supplier does not meet these requirements will get a number of sanctions.

Case 02 / KPPU-L / 2005 concerning the terms of trade (trading terms) PT.CI to suppliers (suppliers) are not directly related to the existence of traditional markets because matter and retail supplier relationships. Case 02 / KPPU-L / 2005 is a competition between retail companies are equivalent (equal playing field) that is between PT.CI with other retail establishments such as Giant, Hypermart and others. However, the case 02 / KPPU-L /2005 indirectly related to the existence of traditional markets at least by two (2) reasons namely:

First, the application of the terms of trade (trading terms) minus margin to make a modern shop (in this case PT.CI) for supply of goods at lower prices from suppliers (suppliers) from other retailers. The imposition of terms of trade (trading terms) due to the supplier company is dependent upon the PT.CI that has consumers in the upper middle class, a strategic location in the Greater Jakarta and other factors. By obtaining the supply of cheaper goods from the supplier making the PT. CI can offer the product at a cheaper price than the traditional market. Thus prohibiting the application of the requirements of the trade (trading terms) in the Commission's decision affects the tradisional market presence also in the retail sector.

Second, Decree No. 02/KPPU-L/2005 gives a sense of fairness for the smallbusiness (in this case the supplier). Decision 02 / KPPU-L / 2005 can be categorized as progressive because the decision had been put on fairness even if contrary to the principles of competition. The principle of competition is being violated by the Commission in order to provide a sense of fairness for small businesses is the principle of non-discrimination. In this case the Commission's Decision to give privileges to small businesses and provide discrimination to large businesses (PT.CI). Thus the decision 02 / KPPU-L / 2005 meets the principles of fairness in the inequality/ imbalances (al-'adalah al-tafâwut) by Sayyid Qutb. ${ }^{65}$

Principles of non-discrimination is a general principle in competition law, but in terms of the imbalance between large enterprises and small businesses, the principles of fairness should be based on fairness for businesses from the weaker position.

Application of the terms of trade is in contrary with the principles of Islamic law that principle ta'alluq market i.e. conditional agreement.Principles of Islamic economic laws every business is free to determinethe transaction or agreement. Agreement with the requirements if the seller is not allowed to hold on to the condition because the agreement has the same sort of agreement with coercion and contains gharar (not clear), because a person may conduct a business transaction if agreed to do something.In the matters relating

${ }^{64}$ Listing fee is a fee for registration of new products into existing systems and to programs on the computer(bar code)as well as for the cost of rearrange products that already exists.

${ }^{65}$ Quthb, al-'Adalah al-Ijtimaiyyah, p. 36. 
to the terms of the sale and purchase that requires unequal conditions favorable to one party only. ${ }^{66}$

\section{Conclusion}

Fair market built on the paradigm that the market not only as a business institution, but also religious and social institutions are based on brotherhood (ukhuwwah) and helping each other (ta'awun). The principle of brotherhood and mutual help necessitates every business to mutual respect, mutual responsibility and not feel self-satisfied look of success while others marginalized.

Based on the principles of fraternity and the nature of ownership, the market as a place of economic activity that is needed by all people should become public property(almilkiyyah al-'ammah) where everyone can access the market without being hindered. Human equality to market access raises independence and responsibility for doing good (ihsan) to other businesses in the form of mutual cooperation between the guard and mutual businesses.

In the context of the market in Indonesia, to achieve market fairness, it is necessary to optimize the concept of ownership of the market as a form of public ownership (al-milkiyah al-ammah) in a market regulation. The concept of common ownership market as intended to prevent the market is not only businesses which is owned by certain business (strong) and marginalize small businesses and thus creating a society that is not harmonious. Market regulation should restrict ownership only market owned and managed by the state. One form of legal entity offer is a legal entity of waqf market as an instrument of Islamic law that is common ownership in nature.

Market fairness system can be realized by strengthening the cooperation between the traditional and the modern market with the principle of sharing, have a model of cooperation, the distribution of products as well as other forms are based on the principle of balance between the parties. The principle of cooperation and the results also prevent the occurrence of adverse cooperation of the parties as to carry out the terms of trade (trading terms) which harm small business.

\section{References}

Abî Shaybah, Abû Bakr 'Abd Allâh bin Muhammad. Al-Kitab al-Musanniffi al-Ahadis wa al-Athar, Juz. IV. t.t, 1409/1989.

Al-Dâr al-Mukhtâr \& Ibn Abî Dîn in Husain Syahatah dan Siddiq Muh. Amin Adh-Dhahîr. Transaksi dan Etika Bisnis Islam, terj. Saptono Budi Satryo and Fauziah. Jakarta: Visi Insani Publish in 2005.

\footnotetext{
${ }^{66}$ H.A. Jazuli, Kitab Undang-undang Hukum Perdata Islam, p. 33.
} 
Al-Samhudi, Nûr al-Dîn Abû Hasan." Wafa' al-Wafa' bi-Akhbar Dâr al-Mustafa, " in Cengiz Kallek, Madinah Market, Encyclopaedia Islamic Economics, Principles, Definition and Methodology, Vol. I. London: FIF, t.p., 2009.

Al-Sadr, Muhammad Baqir Ash. Parent Book of Islamic Economic. Jakarta: Zahra, 2008.

Al-Zuhaili, Muhammad Musthafa. Al-Qấidah al-Fiqhiyyah wa Tathbiqiha fi al-Mâzahib al-Arba'ah. Juz I. Dimsyiq: Dâr al-Fikr, 2006.

Antonio, Muhammad Syafi'i. Bank Syariah: Wacana Ulama dan Cendekiawan. Jakarta: Tazkia Institut, 1999.

Al-Syaukani, Muhammad 'Ali, Nail al-Author. Egypt: Musthafa al-Babi al-Halabi, t.t.

Bonine, Michael E. Islam and Commerce: Waqf and the Bazaar of Yazd, Iran (Islamic und Handel: Waqf und der Bazar von Yazd, Iran). Erdkunde, Bd.41, H. 3 September. 1987.

Behechti \& Bahonar. Philosophy of Islam. Iran: Ansyariyan Publication, 1990.

Chapra, M. Umar. Islam and Economics Development. New Delhi: Adam Publishers \& Distributors, 2007

Djamil, Fathurrahman. Hukum Ekonomi Islam: Sejarah, Teori dan Konsep. Jakarta: Sinar Grafika, 2013.

Esposito, John L. "the Islamic Threat: Myth or Reality?," in Zafar Iqbal and Mervyn K. Lewis, An Islamic Perspective on Government. UK: Edward Elgar Publishing, Inc, 2009.

Fazlurrahman. Islam and Modernity, Trasformation of Intelectual Tradition. Chicago: The University of Chicago Press, 1982.

Hasan, Abdul Halim, et al. Tafsir al-Qur'an Karim. Medan: Firma Islamiyah, 1957.

Hatamlah, Muhammed Abdah. the Andalusia Economic Era Encyclopaedia Islamic Economics, Principles, Definition and Methodology, Vol. I. London: FIF, 2009.

Hoetoro, Arief. Ekonomi Islam, Pengantar Analisis Kesejarahan dan Metodologi. Surabaya: Bayumedia \& BPFE Unibraw, 2007.

Islahi, Abdul Azim. Konsep Ekonomi Ibnu Taymiyah, terj. Anshari Thayib, Surabaya Bina Ilmu, 1997.

Imani, Kamal Faqih. Tafsir Nurul Qur'an. Jakarta: al-Huda, 2004

Islahi, Abdul Azhim. Economic Concept of Ibn Taymiyah. Leicester UK: The Islamic Foundation, 1998.

Ibn Shabbah, Abu Zayd 'Umar Ibn Shabbah. Tarîkh al-Madînah al-Munawwarah, Juz II. Jeddah, 1979.

Jazuli, H.A. Kitab Undang-undang Hukum Perdata Islam. Bandung: Kiblat Press, 2002.

Khan, M. Fahin. Essay in Islamic Economic. United Kingdom: the Islamic Foundation, 1995.

Kamali, Mohammad Hashim, "Tafsir (Price Control) in Islamic Law," the paper was prepared for Colloquim Entitled" The Bazaar in the culture and civilization of the world of Islam, which was to been held in Tabriz, Iran. 
Kister, M. J. The Market of Prophet, Journal of the Economic and Social History of the Orient, Vol. 8, No. 3, 275, (Dec., 1965).

Kupita, Wede and Rahadi Wasi Bintoro, Zoning Policy Implementation Traditional Market and Modern Market (Studies in Purbalingga).

Madjid, Nurcholish. Islam, Kemodrenan dan Keindonesiaan. Bandung: Mizan, 1987.

Maududi, Sayyid Abul A'la. First Principles of Islamic Economics, transl. Ahmad Imâm Shafaq Hashemi. UK: Islamic Foundation, (2011 M/1432 H).

Al-Mawardi. "Al-'Adalah Concept in Islamic Economic Perspectives," in Journal of Islamic Law: Vol.VII, No. 5, July, 2007.

Nuruddin, Amiur. Keadilan dalam al-Qur'an. Jakarta: Hijri Pustaka Utama, 2008.

Private Do not Go, Kompas, Monday, April 28, 2014.

Quthb, Sayyid, al-Adalah al-Ijtimaiyyah fi al-Islâm. Egypt: Dâr al-Syuruq. 1979 M.

Rahman, Justice S. A. The Majelle. Lahore: Law Publishing Company, 1980.

Rahman, Afzalur. Doktrin Ekonomi Islam. Yogyakarta: Dana Bhakti Wakaf, 1995.

Ridwan. Negara dan Rakyat: Konsep Kepemilikan Tanah menurut Hukum Islam. Jakarta: Training and Development Agency and the Ministry of Religious Affairs, 2010.

Ross, Stephen F. Principles of Antitrust Law. Wetbury, New York: The Foundation Press, Inc. 1993.

Shihab, M. Quraish. Tafsir al-Misbah. Jakarta: Lentera Hati, 2002.

Silalahi, M. Udin. "Persaingan Di Industri Ritel Ditinjau Dari Aspek Hukum Persaingan Usaha," dalam Jurnal Hukum Bisnis, 2008.

Simon, Robert. Meccan Trade and Islam (Problem of Origin and Structure, transl. Feodora Sos. Hungaria: Akademia Kiado, Budapest, 1989.

The Commission's Decision 02/KPPU-L/2005.

The Trade Ministery Regulation No. 53 Year 2008.

Watt, W. Montgomery. Pergolakan Politik Islam, terj. Hamid Fahmi Zarkasyi. Jakarta: Beunebi Cipta, 1987.

Hasan, Zulkifli. "Islamic Perspectives on the Competition Law and Policy," in files.wordpress. com/2008/.../Islam-and-competition-policy, 